\title{
Propagation and Possible Allelopathic Effects of Vernoniazeylanica on Selected Bioassay Species
}

\author{
S. H. S. Senarathne ${ }^{1}$ and S. S. Udumann ${ }^{1}$
}

\begin{abstract}
Vernonia zeylanica (L.) belongs to the family Asteraceae, is one of the major endemic weed species present in coconut (Cocos nucifera L.) plantations of the tropics, which propagates very easily. There is a possibility that this plant could also possess allelopathic effects, but this has not been scientifically tested. Thus, a study was carried out to determine the seed germination of $V$. zeylanica under soil moisture stress conditions, shoot propagation methods and possible allopathic effects of this species, on selected species in bioassay tests. Germination of V. zeylanica seeds was not observed at higher osmotic potential $(-0.9 \mathrm{MPa})$. The highest sprouting percentage of this species were obtained with soft wood cuttings. The aqueous leaf extract was highly phytotoxic, and it significantly reduced germination and seedling growth of all bioassay species tested. Full strength $\left(33.3 \mathrm{~g} \mathrm{~L}^{-1}\right)$ aqueous extracts of leaves significantly reduced the germination percentage, root and hypocotyl growth rates of all species tested. The inhibitory effects were often dependent on concentration. However, the degree of inhibition varied among the test plant species. The seedling emergences of all four tested plants were severally inhibited when planted in $V$. zeylanica contaminated soil. The results indicated that incorporated aqueous leaf extract of $V$. zeylanica and its rhizosphere contaminated soil can suppress seed germination, seedling growth and seedling emergence of certain plant species indicating a possible allelopathic effect.
\end{abstract}

Key words: Vernonia zeylanica, allelopathic, seed germination

\section{Introduction}

Vernonia zeylanica (L.) is an herbaceous perennial deep-rooted species that belongs to the family Asteraceae and is one of the major endemic weed species present in coconut (Cocos nucifera L.) plantations in the tropics. It competes for soil moisture, nutrients and light especially when palms are at the seedling stage. Jayaweera (1982) stated that it is an understory shrub with many straggling, divaricated cylindrical branches when young. Therefore, it grows vigorously by covering the ground of coconut plantations under both moist and dry conditions. Additionally, it interferes and causes inconvenience to estate management practices such as manuring and harvesting of nuts. Crop growth and productivity are reduced considerably due to these factors. As this species is perennial in growth habit, it can be propagated by seeds or vegetatively by cuttings.

Allelopathy is defined as the direct influence of a chemical released from one plant on the development and growth of another plant. Allelochemicals are secreted to the rhizosphere and can suppress the growth of neighboring plants (Bais et al., 2004) and might reduce the cost of weed management (Iqbal and Cheema, 2007). However, allelopathy alone might not be a perfect weed management technology; it could be a supplementary method in an integrated weed management program. A large number of allelochemicals, which are released by many weed species, have inhibitory effects on the crops (Jabeen, et al., 2013). It is reported that allelochemicals which are liberated by many plants from leaves, stem, roots, fruit and seeds as residues, exudates and leachates interfere with the growth of other plants (Asgharipour and Armin, 2010). These allelochemicals are being released into the soil and show inhibitory influences on the development and growth of surrounding plants (Abdul et al., 2012). However, the allelopathic effect of Vernonia zeylanica weed species is not fully understood.

\footnotetext{
${ }^{1}$ Coconut Research Institute, Sri Lanka
} 
Therefore, the overall objectives of the present study were to determine the propagation and possible allelopathic effect of Vernonia zeylanica on selected bioassay species including tomato (Lycopersicon esculentum) chilies (Capsicum annum L.) radish (Raphanus sativa and blue rattle pod (Crotalaria verrucose L.).

The specific objectives of this study were to; (i) determine the effect of moisture stress on seed germination of Vernonia zeylanica; (ii) identify shoot propagation methods for Vernonia zeylanica and (iii) effects of aqueous extracts of Vernonia zeylanica leaves and contaminated rhizosphere soil on seed germination of selected bioassay species.

\section{Materials and methods}

The experiments were carried out in a plant house and laboratory of the Coconut Research Institute located in the Low county Intermediate Zone of the North-Western province of Sri Lanka from April to August 2016. Inside the plant house, Petri dishes and planting trays received photosynthetically active radiation (PAR) ranging from $500-1150$ $\mu \mathrm{mol} \mathrm{m} \mathrm{m}^{-2} \mathrm{~s}^{-1}$ and the average day and night temperature were in the range of $30-34^{\circ} \mathrm{C}$ and $26-30^{\circ} \mathrm{C}$, respectively. Relative humidity varied between $35-60 \%$ during the day and $20-27 \%$ during the night. In the bioassay S. lycopersicum, $C$. annum, $R$. raphanistrum subsp. sativus and $C$. verrucosa were used as the test species due to their high sensitivity to the phototoxic activity of $V$. zeylanicaas observed in a preliminary study. Seeds of $V$. zeylanica were collected from five different locations in the major coconut growing regions of Sri Lanka during February and March 2016 and were stored at $5^{\circ} \mathrm{C}$ under dark conditions. Seeds of L. esculentum, C. annum and $R$. sativa were taken from the Seed and Plant Materials Development Center, Department of Agriculture, Sri Lanka and those of $C$. verrucosa were obtained from the same locations from which the seeds of $V$. zeylanica were gathered. Treatments of the experiments were arranged in a Complete Randomized Design (CRD) with 10 replicates (each Petri dish and a planting plot representing one replication of a single species in each trial) in the respective studies.

\section{Effect of moisture stress on seed germination of Vernonia zeylanica}

Aqueous solutions of polyethylene glycol (PEG)were prepared to obtain osmotic potentials of $0,-0.3,-0.4,-0.6$, and $-0.9 \mathrm{MPa}$ by dissolving 0,154, 191, 230 or $297 \mathrm{~g}$ of PEG in $1 \mathrm{~L}$ of deionized water (Michel and Kaufmann, 1973). Thereafter, 50 seeds of V. zeylanica were placed in $9 \mathrm{~cm}$ diameter Petri dishes containing two filter papers. The filter papers were moistened separately with $5 \mathrm{~mL}$ of deionized water and the respective test solutions and the Petri dishes were placed in the plant house. The germination percentage of $V$. zeylanica seeds was recorded after 30 days of incubation. This experiment was repeated three times.

\section{Identification of suitable shoot propagation methods of Vernonia zeylanica}

Shoots of $V$. zeylanica were collected from randomly selected $V$. zeylanica plants and they were separated into hardwood, semi hardwood and soft woods. Then the separated shoots were cut into $10 \mathrm{~cm}$ length. The cut surface was immediately immersed in water to avoid trapping air bubbles in the stems. The study used 200 hardwood, semi hardwood and soft wood cuttings and they were planted in a Red Yellow Podzolic soil using trays as containers. Each treatment was replicated four times and trays were kept inside the plant house. All requirements for the sprouting of different cuttings were supplied.

The data was collected as a percentage of sprouted cuttings (No. of sprouted cuttings/ Total number of cuttings) x 100 .

\section{The effect of aqueous extract of Vernonia zeylanica dried leaves on seed germination and seedling growth of selected bioassay species}

Matured leaves of $V$. zeylanica were collected from five different locations within the major coconut growing regions of Sri Lanka from February to April 2016. The leaves were air-dried for 1 week, ground into small pieces. Different weights $(33.35,16.67$ and $8.30 \mathrm{~g})$ of leaf debris were put in a flask that contained 1 $\mathrm{L}$ of distilled water. The solutions were shaken for 12 hours at room temperature. The extract was strained through four layers of cheesecloth, then vacuum filtered through two layers of filter paper (Whatman no. 02) (White et al., 1989).

Three concentrations of the aqueous extract were used, the concentrations of fullstrength half strength and quarter strength were $33.35,16.67$ and $8.3 \mathrm{~g} \mathrm{~L}^{-1}$, respectively (dilution was made with distilled water). Distilled water 
was used as the control. The extracts were stored at $5^{\circ} \mathrm{C}$ until used. All the seeds of the test plant species were surface-sterilized for 1 minute in a $50 \%$ sodium hypochlorite solution, rinsed with running water for 10 minutes, and air-dried. Fifty seeds from each selected bioassay species were placed separately in $9 \mathrm{~cm}$ diameter Petri dishes lined with cotton wool. The solutions and distilled water were applied in $5 \mathrm{~mL}$ volumes per dish. The Petri dishes were kept in the plant house for 72 hours at $28-30^{\circ} \mathrm{C}$. All treatments were replicated 10 times. Seed germination percentage, root and hypocotyl length of the selected bioassay species were measured 3 weeks after seed placement (White et al., 1989).

\section{Effect of residual toxicity of contaminated} soil on seed germination of bioassay species

Contaminated soil was collected to a depth of $10 \mathrm{~cm}$ from a field where $V$. zeylanica had been growing for the last 5 years. Soil from a field where $V$. zeylanica had not been growing was used as a control. Soil samples were airdried and sieved through a $2 \mathrm{~mm}$ mesh. Ten $\mathrm{g}$ were taken from each soil sample and uniformly spread individually in $9 \mathrm{~cm}$ diameter Petri dishes. Fifty seeds of the selected bioassay species were placed uniformly on the soil and covered with a further $10 \mathrm{~g}$ of the same soil. The soil was moistened to field capacity with distilled water. The dishes were kept in a plant house at $27-30^{\circ} \mathrm{C}$. Each treatment was replicated 10 times.

\section{Statistical analysis}

An Analysis of Variance (ANOVA) using the statistical software SAS was carried out on the data from all experiments and the significance of observed differences was tested using Least Significant Differences (LSD) at 5\% probability (SAS Institute 1999).

\section{Results and Discussion} Impact of moisture stress on seed
germination of Vernonia zeylanica

Germination of $V$.zeylanica seeds decreased when the osmotic potential increased from 0 MPa to $-0.9 \mathrm{MPa}$ (Table 1). Application of higher osmotic potentials (-0.9 MPa) did not facilitate germination while the highest germination percentages $(12.4,34.8$ and $42.8 \%)$ were found in the control treatment (0 MPa). Treatment 2 and $3\left(\mathrm{~T}_{2}\right.$ and $\left.\mathrm{T}_{3}\right)$ induced seed germination

\begin{tabular}{cccc}
\hline & \multicolumn{3}{c}{ Seed germination \% } \\
\cline { 2 - 4 } Treatments & $\begin{array}{c}1^{\text {st }} \\
\text { round }\end{array}$ & $\begin{array}{c}2^{\text {nd }} \\
\text { round }\end{array}$ & $\begin{array}{c}3^{\text {rd }} \\
\text { round }\end{array}$ \\
\hline $\mathrm{T}_{1}$ Control & 12.4 & 34.8 & 38.8 \\
$\mathrm{~T}_{2}(-0.3 \mathrm{MPa})$ & 10.8 & 22.6 & 24.5 \\
$\mathrm{~T}_{3}(-0.4 \mathrm{MPa})$ & 10.8 & 18.3 & 20.4 \\
$\mathrm{~T}_{4}(-0.6 \mathrm{MPa})$ & 0.0 & 5.5 & 4.2 \\
$\mathrm{~T}_{5}(-0.9 \mathrm{MPa})$ & 0.0 & 0.0 & 0.0 \\
Signifiance & $*$ & $*$ & $*$ \\
$\mathrm{LSD}(\mathrm{P}=0.05)$ & 6.51 & 10.6 & 10.8 \\
\hline
\end{tabular}

Table 1. Effect of soil moisture stress (osmotic potential - MPa) on seed germination percent of Vernonia zeylanica

but the effect of these two treatments on seed germination was not significantly different. However, no seed germination was observed in the high moisture stress conditions at -0.9 $\mathrm{MPa}$. The results suggested that under higher moisture stress conditions, germination of $V$. zeylanica seeds was suppressed.

Moreno and McCarthy (1994) found that crabgrass (Digitaria sp.) germination was reduced by up to $70 \%$ at osmotic potentials ranging from -0.4 to $-0.8 \mathrm{MPa}$. The germination of the sensitive plant (Mimosa pudica L.) and Caesarweed (Urena lobata L.) was sensitive to simulated water stress and less than $12 \%$ of the M. pudica and $U$. lobata seeds germinated at osmotic potential below -0.4 MPa (Senarathne and Sangakkara, 2010). This weed species seems to be best adapted to germinate in a moist environment, and germination in the field may depend on adequate water availability.

\section{Shoot propagation methods of Vernonia zeylanica}

A significantly higher sprouting percentage was observed in soft wood cuttings $\left(\mathrm{T}_{3}\right)$ when compared to hardwood ( $\mathrm{T}_{1}$ ) and semi hardwood cuttings $\left(\mathrm{T}_{2}\right)$ (Table 2 ). The highest sprouting percentage (89\%) was found in soft wood cuttings at 12 days after planting, and the sprouting percentage in hard wood cuttings in the same period was $30.5 \%$. However, the highest sprouting percentage $(36 \%)$ of hard wood cuttings was observed 15 days after planting. 


\begin{tabular}{lcccc}
\hline & \multicolumn{5}{c}{ Percentage of sprouting } \\
\cline { 2 - 5 } Treatments & $\begin{array}{c}6 \text { days } \\
\text { after } \\
\text { planting }\end{array}$ & $\begin{array}{c}9 \text { days } \\
\text { after } \\
\text { planting }\end{array}$ & $\begin{array}{c}12 \text { days } \\
\text { after } \\
\text { planting }\end{array}$ & $\begin{array}{c}15 \text { days } \\
\text { after } \\
\text { planting }\end{array}$ \\
\hline $\mathrm{T}_{1}$ Hardwood & 12.4 & 34.8 & 38.8 & 36.0 \\
$\mathrm{~T}_{2}$-Semi & 10.8 & 22.6 & 24.5 & 61.0 \\
hardwood & 10.8 & 18.3 & 20.4 & 85.0 \\
$\mathrm{~T}_{3}$-Softwood & $*$ & $*$ & $*$ & $*$ \\
Signifiance & 6.51 & 10.6 & 10.8 & 18.81 \\
\hline LSD (P =0.05) & & & & \\
\hline
\end{tabular}

Table 2. Effect of shoot maturity on sprouting of Vernonia zeylanica cuttings

The sprouting percentage of hard wood, semi hard wood and soft wood cutting 6 days after planting were $25.5,50.0$ and $75.4 \%$, respectively. Except in $\mathrm{T}_{3}$, the percentage of sprouting was increased with the increasing number of days after planting.

\section{The effect of aqueous extract of Vernonia zeylanica dried leaves on seed germination and seedling growth of selected bioassay species}

Aqueous extracts from dry leaves of $V$. zeylanica reduced the germination percentages of $L$. esculentum, $C$. annum, $R$. sativa and $C$. verrucosa when compared to the control treatment (Table 3).

The lowest seed germination $(10.4 \%)$ was found in L. esculentum seeds at the highest concentration of aqueous extract of $V$. zeylanica $\left(\mathrm{T}_{4}\right)$ whilst the highest germination percentage $(83.2 \%)$ was recorded in $C$. verrucosa seeds in the control treatment $\left(\mathrm{T}_{1}\right)$. The inhibitory effect of $V$. zeylanica leaf aqueous extract on seed germination of the above bioassay species could be due to an allelopathic effect. The overall results suggested that the leaf aqueous extract of V. zeylanica $(\mathrm{P}>$ $=0.05$ ) suppressed the seed germination of $L$. esculentum, $C$. annum, $R$. sativa and $C$. averrucosa. These results are supported by the findings of Mishra and Singh in 2010, who reported that aqueous leaf extract of Lantana camara produced an inhibitory effect on the growth of Parthenium hysterophorus and caused a significant inhibitory effect on seed germination, root and shoot elongation and development of lateral roots of six popular agricultural crops.

\begin{tabular}{lcccc}
\hline & \multicolumn{4}{c}{ Seed germination (\%) } \\
\cline { 2 - 5 } $\begin{array}{c}\text { Treatments } \\
\text { (g dried leaf } \mathrm{L}^{-1} \text { ) }\end{array}$ & $\begin{array}{c}\text { Lycoper- } \\
\text { sicon } \\
\text { esculentum }\end{array}$ & $\begin{array}{c}\text { Capsicum } \\
\text { annum }\end{array}$ & $\begin{array}{c}\text { Raphanus } \\
\text { sativa }\end{array}$ & $\begin{array}{c}\text { Crotalaria } \\
\text { verrucosa }\end{array}$ \\
\hline $\mathrm{T}_{1}$ Control(Water) & 70.8 & 76.0 & 82.8 & 83.2 \\
$\mathrm{~T}_{2} 8.3$ & 45.6 & 63.6 & 61.6 & 69.2 \\
$\mathrm{~T}_{3} 16.7$ & 24.0 & 47.6 & 47.6 & 51.6 \\
$\mathrm{~T}_{4} 33.3$ & 10.4 & 26.8 & 26.8 & 27.6 \\
Signifiance & $*$ & $*$ & $*$ & $*$ \\
LSD (P=0.05) & 9.01 & 5.14 & 6.83 & 10.35 \\
\hline$*$ Significant & & & &
\end{tabular}

Table 3. Effect of aqueous extracts of dried leaves on seed germination of bioassay species Effect of the aqueous extract of dried leaves
on the root elongation of the bioassay species

Root growth of the weeds was significantly reduced by the different concentrations of aqueous extracts of $V$. zeylanica. Results have shown that the inhibitory effects of the aqueous extracts increased with their concentrations. However, variations in the response were observed in the selected bioassays, where $C$. verrucosa produced the highest and $L$. esculentum the lowest root length under the influence of the aqueous extracts.

At the highest concentration (33.35 $\left.\mathrm{g} \mathrm{L}^{-1}\right)$, L. esculentum, C. annum, R. sativa and C. verrucosa root growth was suppressed by $100,87.4,100$ and $72.9 \%$ respectively, when compared to that of plants in the control treatment (Figure 1). At quarter-strength $\left(8.3 \mathrm{~g} \mathrm{~L}^{-1}\right)$ the root length of $L$. esculentum, C. annum, $R$. sativa and $C$. verrucosa decreased by $85.0,61.2,80.0$ and $32.7 \%$, respectively compared to root growth of control. Aqueous extracts of some weed species leaves have a negative impact on weed seedling growth through allelopathy. The reduction in weed seedling root length may be attributed to the reduced rate of cell division and cell elongation related to the presence of allelochemicals in the extracts (Fariba et al., 2007).

Effect of the aqueous extract of leaves on the hypocotyl elongation of the bioassay species

The aqueous extract was either inhibitory or stimulatory to the hypocotyls growth of selected bioassay species depending on the 


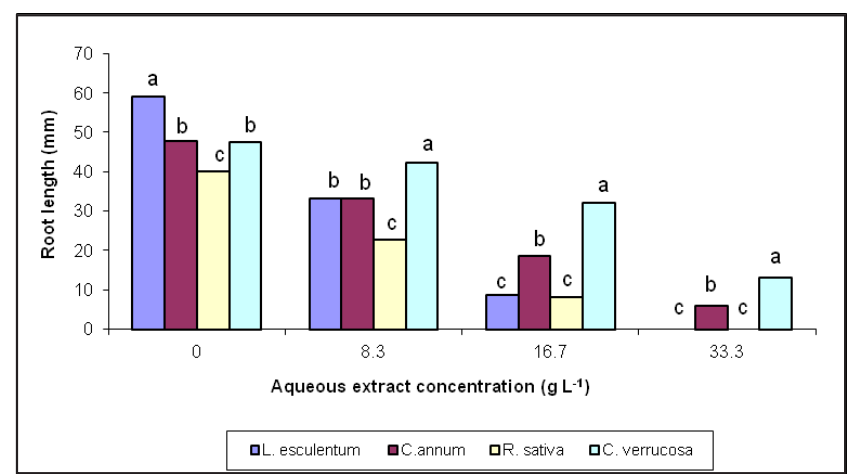

Figure 1. Changes of the root length of the selected bioassay seedlings in response to different concentration of the aqueous extract of Vernonia zeylanica

(Bars with the same letter are not significantly different within extract concentration $\mathrm{P}=0.05$ )

extract concentration and the plant species. The application of the aqueous extract at fullstrength resulted in complete inhibition of $L$. esculentum, and $R$. sativa growth. At this concentration, hypocotyl elongation of $C$. annum and $C$. verrucosa hypocotyls was suppressed by 76.3 and $78.6 \%$, respectively compared to the control plants. At quarter-strength, the hypocotyls growth of all the selected bioassay was reduced by $78.4,56.3,78.0$ and $46.1 \%$, respectively, when compared to those of the control treatment.

In response to the half-strength extract, the hypocotyl lengths of all the selected bioassay species were decreased by $33.0,24.8,40.7$ and $30.9 \%$ respectively, while $L$. esculentum and $C$. annum did not show any significant change in comparison to the control treatment (Figure 2).

\section{Effect of residual toxicity of contaminated soil on seed germination of bioassay species}

Soil collected from the $V$. zeylanic arhizosphere had a strong inhibitory effect on the seed germination of the bioassay species $L$. esculentem, $R$. sativa and $C$. annum (Figure 3 ). However, the allelopathic effect of $V$. zeylanica on C. verrucosa seeds was not significant. The lowest germination percentage (32.8\%) was recorded in L. esculentem seeds, when these seeds were sown on the V. zeylanica contaminated soil, while the highest germination percentage was found in C. verrucosa seeds (56.3\%), compared to the germination percentage of other selected bioassays (Figure 3). This agrees with the results of Chung and Miller (1995) who reported the inhibitory effect of soil collected from the area

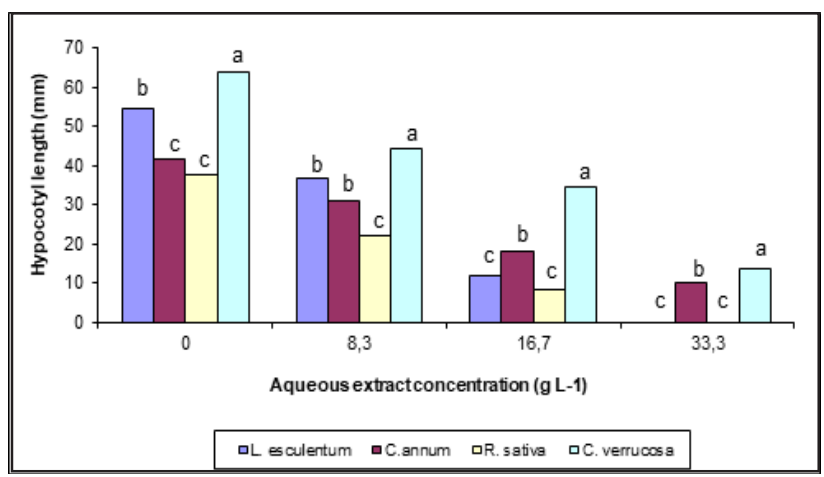

Figure 2. Changes of the length of the hypocotyl of the selected bioassay seedlings in response to different concentration of the aqueous extract of Vernonia zeylanica

(Bars with the same letter are not significantly different within extract concentration $\mathrm{P}=0.05$ )

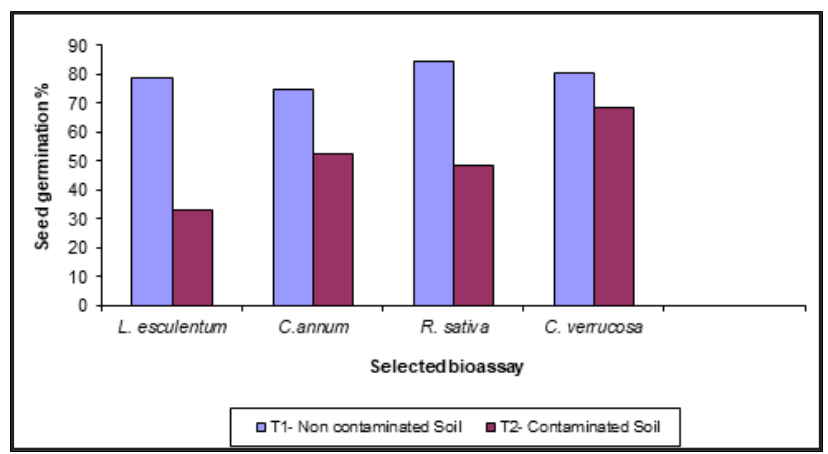

Figure 3. Effect of rhizosphere soil of Vernonia zeylanica on the seed germination percentage of selected bioassay species

surrounding alfalfa (Medicago sativa L.) plants on bioassay test species. This inhibition may be due to the release of phytotoxic substances by the root itself or through interaction between microorganisms and tissue litter. However, this interpretation needs further study as several factors are involved in an allelopathic activity and seed germination. Besides, allelochemicals released into the rhizosphere exert a significant impact on nutrient availability, dynamics and uptake by the plant. A broader knowledge of the effects of plant allelochemicals on mineral nutrient soil cycles, heavy metal detoxification and nutrient solubility can enhance the nutrient use efficiency through a reduction of their losses and the development of a more efficient and sustainable fertilization technique (Aurelio et al., 2019). 


\section{Conclusions}

According to the given results, it was suggested that under higher moisture stress conditions germination of $V$. zeylanica seeds was suppressed and soft wood cuttings have the highest sprouting percentage of $V$. zeylanica.

The selected bioassay species were more sensitive to the inhibitory effects of aqueous extracts and contaminated rhizosphere soil of $V$. zeylanica. Hence, it can be suggested that $V$. zeylanica has a possible allelopathic potential and releases allelopathic substances to the environment. However, the species sensitivity to allelochemicals and extent of inhibition varies between species. The allelopathic effect of $V$. zeylanica may be an important mechanism involved in the invasive success of this plant. Under natural conditions, where a great number of interactions with other organisms occur, these allelopathic effects can enhance or restrain plant growth and species diversity. Field experiments must be carried out to test the effectiveness of the allelopathic potential of the above species under natural conditions.

\section{References}

Abdul, M., Zubeda C. and Zahir M., 2012. Allelopathic assessment of fresh aqueous extracts of chenopodium album L. for growth and yield of wheat (Triticum aestivum L.). Pak. J. Bot., 44(1): 165-167.

Asgharipour, M. R. and Armin, M., 2010. Inhibitory effects of Sorghum halepens root and leaf extracts on germination and early seedling growth of widely used medicinal plants. Adv. Environ. Biol, 4(2): 316-324.

Aurelio, S., Cristina, A. and Giovanni, M., 2019. Plant allelochemicals: agronomic, nutritional and ecological relevance in the soil system. Plant and Soil, 442: 23-48.

Bais, H. P., Vepachedu R., Gilroy S., Callaway R. M. and Vivanco J. M. 2003. Allelopathy and exotic plant invasions from molecules and genes to species interactions. Weed Science, 301: 1377 - 1380.

Chung, M. and Miller, D. A. 1995. Effects of alfalfa plant and soil extract on germination and growth of alfalfa. Agronomy Journal, 87: 762-767.
Fariba M., Javad K., Mohammed A. B. and Morteza N. 2007. Allelopathic potential of Trifolium resupinatum $\mathrm{L}$. (Persian clover) and Trifolium alexandrium L. (Berseem clover), Weed Biology and Management, 7: 178-183.

Humphreys, L. R. 1991. Tropical Pasture Utilization. Cambridge University Press, Cambridge, New York. 226 -227.

Iqbal J., Cheema Z. A., An M. 2007. Intercropping of field crops in cotton for the management of purple nutsedge (Cyperus rotundus L.). Plant Soil, 300: 163-171.

Jayaweera D. M. A. 1982. Medicinal Plants (Indigenous and Exotic) Used in Ceylon. The National Science Council of Sri Lanka, Metland Place, Colombo 07, Sri Lanka. 76-77.

Jabeen, N., Ahmed, M., Shaukat, S.S. and IramusSlam. 2013. Allelopathic effects of weeds on wheat (Triticum aestivum L.) germination and growth. Pak. J. Bot., 45(3): 807-811.

Liyanage, M. de. S. 1999. Guide to scientific cultivation and management of coconut. Hitech Printers, Nugegoda, Sri Lanka, 1: pp. 61-65,

Michel B. E. and Kaufmann M. R. 1973. The osmotic potential of polyethylene glycol 6000. Plant Physiol., 51: 914-916.

Mishra, A. and Singh, R. 2010. Comparative study of the effect of Lantana camara extract of different parts on seed germination of Parthenium hysterophorus. International Journal of Plant Science, 5(1): 74-75.

[SAS] Statistical Analysis Systems, 1999. SAS 1, STAT Users Guide, Release, 7.00 Cary, NC: Statistical Analysis Systems Institute, pp. 1028.

Senarathne, S. H. S. and Sangakkara, U. R. 2010. Influence of moisture, $\mathrm{pH}$, depth of burial and submerged conditions on seed germination and seedling emergence of major weed species in coconut plantations of Sri Lanka. Korean Journal of Weed Science, 30(3): 206-214.

White R. H., Worsham A. D. and Blum U. 1989. Assessment of weed and crop fitness in cover crop residues for integrated weed management. Weed Science, 46: 595-605. 